\title{
Sampling Palms for Lethal Yellowing and Texas Phoenix Palm Decline Phytoplasmas ${ }^{1}$
}

\author{
Brian W. Bahder and Ericka E. Helmick²
}

\section{Introduction}

In Florida, palms are an economically important group of trees. They are primarily used as ornamentals and have a significant impact on the nursery and landscaping industries. Phytoplasma diseases of palms are of major concern because both lethal yellowing (LY) and Texas Phoenix palm decline (TPPD) cause plant death in a variety of important ornamental palms. Once symptoms appear, the rate of decline is variable, but often is very rapid with the death of the palm in as few as three to five months. Historically, palms that express symptoms or suspected symptoms of phytoplasma disease are sampled and sent to the University of Florida Plant Disease Diagnostic Clinic at the UF/IFAS Fort Lauderdale Research and Education Center (FLREC) to test for phytoplasma. Typically, palms are sampled once symptoms are noticeable, which leaves only a narrow margin for implementing a management decision that could save the palm. Palms may be treated with antibiotics (oxytetracycline $\mathrm{HCl}, \mathrm{OTC}$ ) or quickly removed to reduce the likelihood of the insect vector spreading the phytoplasma to other palms. This narrows the margin for action even more, necessitating a sensitive and rapid test to detect the phytoplasma. Proper sample collection technique is key to getting reliable results as quickly as possible. Collecting good samples is the first and most important step toward managing LY and TPPD phytoplasmas or indeed any palm disease.

\section{Sampling}

When sampling a palm for phytoplasmas, some basic equipment (Table 1) will allow you to obtain a high-quality sample that will yield accurate results. After you assemble all of the equipment and choose a palm to sample, begin by flame sterilizing a drill bit and cooling it off with sterile distilled water (Figure 1). Next, select a location on the trunk approximately two feet (about 0.6 meters) above the ground and drill a hole (Figure 1). Palms contain both living and dead tissues. The brown outermost tissue, called pseudobark, is the dead tissue and should be discarded. Drill through the dead tissue, pull the drill out, clean the drill, and then resume drilling into the living tissue. The depth of the pseudobark is variable among palm species, thus this step involves observation to determine how much to remove. The living tissue is typically an off-white color (Figure 2). Continue drilling to obtain approximately two tablespoons worth (three grams/0.1 oz.) of the living trunk tissue. Without touching the tissue, put it into a plastic zipper-closure bag and seal carefully (Figure 1). The use of nitrile gloves is highly recommended in order to avoid contamination. Excess tissue on the drill bit can be scraped into the bag using a sterile toothpick or individual coffee stir straw. The trunk tissue need not be obtained from the same hole, and in fact it is advisable to take tissue from different spots around the circumference of the trunk, for a total of $0.1 \mathrm{oz} . /$ three grams. Hammer golf tees into the sample holes to seal them and protect the tree.

1. This document is ENY-990, one of a series of the Entomology and Nematology Department, UF/IFAS Extension. Original publication date December 2017. Visit the EDIS website at http://edis.ifas.ufl.edu.

2. Brian W. Bahder, assistant professor, Entomology and Nematology Department; and Ericka E. Helmick, biological scientist II, Entomology and Nematology Department; UF/IFAS Fort Lauderdale Research and Education Center, Davie, FL 33314.

The Institute of Food and Agricultural Sciences (IFAS) is an Equal Opportunity Institution authorized to provide research, educational information and other services

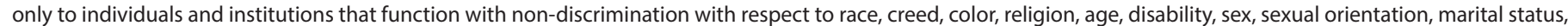

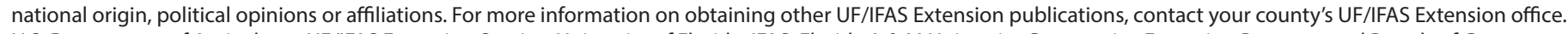
U.S. Department of Agriculture, UF/IFAS Extension Service, University of Florida, IFAS, Florida A \& M University Cooperative Extension Program, and Boards of County Commissioners Cooperating. Nick T. Place, dean for UF/IFAS Extension. 
In order to eliminate cross contamination, if samples are to be taken from more than one tree, then the drill bit must be sterilized between samples by rinsing it with distilled water, flame sterilizing it, and cooling it off with more sterile distilled water before proceeding to the next tree. Label sample bags with the date and locality (Figure 1). All samples taken in the field must be stored immediately in a cooler with ice packs to keep them cold and away from sunlight. Number the samples sequentially and store them in a refrigerator until they are ready to be submitted. If it is at all possible, it is recommended to send samples overnight the day they are taken.

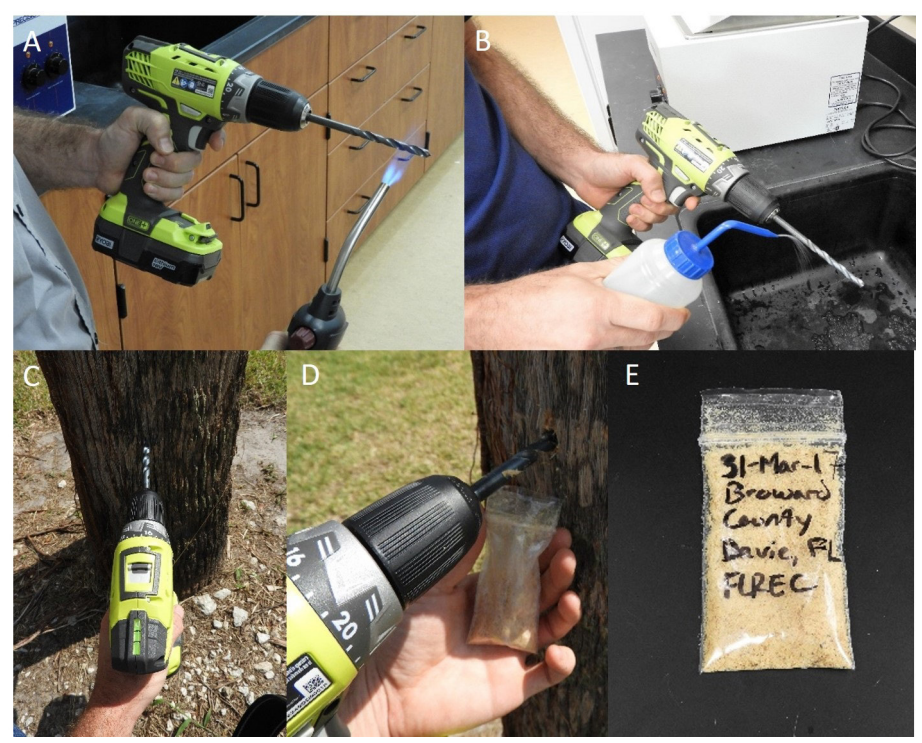

Figure 1. Protocol for palm trunk sampling to test for LY and TPPD phytoplasmas: Heat sterilization of drill bit before drilling for trunk tissue (A), Rinsing drill bit to remove excess tissue/cool after heat sterilization (B), Site selection and removal of the pseudobark so that trunk tissue can be accessed (C), Drilling hole and taking sample of living trunk tissue (D), Properly labeled bag with trunk tissue from symptomatic palm (E).

Credits: Brian Bahder

\section{Submitting Samples}

Complete a Sample Submission form and send it with the samples in the overnight package. The form for submitting palm samples to test for phytoplasma diseases can be found at http://flrec.ifas.ufl.edu/featured-3-menus/research-/ entomology-and-nematology/.

Send samples overnight to the following address:

Attn: Dr. Brian Bahder

University of Florida

Fort Lauderdale Research and Education Center

Vector Entomology Lab

3205 College Avenue

Davie, FL 33314-7719

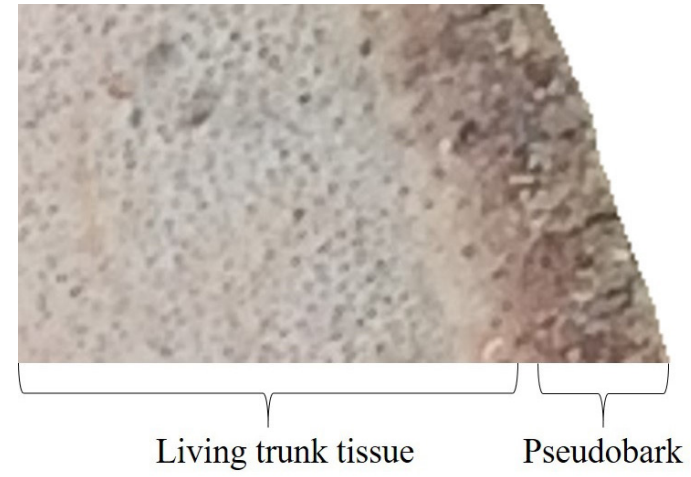

Figure 2. Cross-section of Sabal palmetto trunk highlighting pseudobark and living trunk tissue; note that the thickness of psuedobark will vary among palm species.

Credits: Brian Bahder 
Table 1. Equipment and supplies necessary to take samples from palm trunks to test for phytoplasma disease.

\begin{tabular}{|l|l|}
\hline Item & Checklist \\
\hline Distilled water & \\
\hline Cordless power drill & \\
\hline $5 / 16 "$ Drill bit, 6"-8"long & \\
\hline Trigger-start propane torch & \\
\hline Golf tees & \\
\hline Hammer & \\
\hline Toothpicks or coffee stir straws & \\
\hline Plastic bags & \\
\hline Marker to label samples & \\
\hline
\end{tabular}

Table 2. Working protocol for sampling palm trunk tissue.

1. Rinse drill bit with distilled water to remove any loose material.

2. Flame sterilize drill bit by moving the flame over the entire length for approximately 10 seconds.

3. Cool the drill bit by rinsing with distilled water.

4. Select location(s) on the trunk to drill, and put a plastic bag in place to catch tissue.

5. Begin drilling, removing the pseudobark from the drill with a toothpick.

6. Once you reach the white trunk tissue, allow it to fall into bag. Avoid hand contact with tissue.

7. Use a toothpick or coffee stir straw to push any remaining trunk tissue on the drill bit into the bag.

8. Seal and label the bag.

9. Rinse the drill bit with distilled water.

10. Flame sterilize the drill bit.

11. Insert a golf tee into each sampling hole and hammer it into place to seal hole.

12. Chill the sample on ice or refrigerate it until it is ready to be shipped 